\title{
JORIS VAN SPILBERGEN.
}

1617.

De tweede Nederlander die de aarde omzeilde was Joris van Spilbergen. Na de Oost-Indische Compe. vroeger in Indië en de algemeene Staten, onder anderen bij den slag van Gibraltar in 1607, met veel lof gediend te hebben, was hem in het jaar 1614 door de Bewindhebberen der Oost. Ind. Compe het bevel opgedragen over eene vloot van zes schepen, om daar mede door de Straat van Magelaan naar de Molukken te zeilen en den algemeenen vijand alle mogelijke afbreuk te doen.

Met welken gelukkigen uitslag hij die reize volbragt heeft, lezen wij bij de geschiedschrijvers van dien tijd.

Ruimen dank oogstte hij dan ook daarvoor bij zijne terugkomst in het Vaderland in; terwijl de Bewinthebberen, om te toonen op welken hoogen prijs ze zijne gedane diensten stelden, behalve in eene belangrijke som in geld, in hunne Vergadering van den $8^{\text {sten }}$ Augustus 1617, hem het hierna volgende attest, of zoo ze het noemen Paspoort, ter hand stelden :

De Bewinthebberen der Geoctroyeerde Oost-Ind. Compe. in de vrije Vereenichde Nederlanden, aen alle dengenen die desen sullen sien ofte hooren lesen. Saluijt. Alsoo den E. Joris van Speelbergen in onsen dienst door de Strate Magellanus naer d' Oost-Indië eene reyse als Commandeur over vier groote schepen ende twee jachten aengenomen, des Conincks van Spangiëns vlooten ende schepen gedestrueert ende daervan (met verlies van des vyants drie principale schepen ende sonder 
eenige merckelycke schade of verlies van syn volck ofte schepen) de victorie gerapporteert hebbende, deselve syne reyse (door Godts gratie) loffelyck volbracht ende onse voorschreven (schepen) wel ende behouden in de Moluquos gebracht heeft. Sonder dat wy tot noch toe eenighe seeckere ende in rechte bestendighe advysen ofte rapporten wt d' Indiën verstaen hebben, dat denselven ${ }_{m}$ Commandeur hemgedurende syne voorschreve reyse anders dan wel ende naer behooren soude gecomporteerd hebben; soo en hebben wy hem dese brieven van afscheyt ende attestatie niet connen ofte willen weygeren, om hem te dienen daer ende waer sulcx van noode mochte wesen, ende hebben hem dienvolgende dese acte ende attestatie t' onser Vergaderinge van de $17^{\text {en }}$ binnen dese stad Middelburgh verleendt, deselve met eygen handen van de gecommitteerden van de respective-Cameren doen teeckenen ende met des Compe. segel bevesticht.

In Middelburgh desen 22 Augusto $A^{\circ}$. 1617 .

(Ende was onderteekent, enz.)

Op 't versoeck van den Commandeur Speelbergen nopende syn soons gagie ende eenighe cleyne costen van reysegelt als anderes by hem gepretendeert, is verstaen, dat men hem, mits gevende acquit met renunciatie van alle andere verdere pretentiën, syn reeckeninge sal payeren ende alhier doen betaelen de somma van $f 416: 9$.

Voor zoo veel wij de namen hebben kunnen opsporen der schippers aan wier moed en dapperheid Spilbergen de gelukkige uitkomst van zijne reis te danken had, laten wij die hier volgen:

De groote Son Schipper Reyer Jansz.

De Jager " " Gerrit Jansz.

Meeuken " Jan de Wit.

Eolus " Job Cornelisz.

Morgensterre " Maerten Pietersz.

De Maene " ? ? 
Het schijnt dat toen Spilbergen in het volgende jaar het verhaal van zijne reize in het licht gaf, dit niet naar het genoegen der Bewinthebberen was, die in hunne Vergadering van den $15^{\text {den }}$ Mei 1619 het volgende besluit namen:

"In dese Vergadering gesien synde seeker boeck, geintituleerd: Oost"en West-Indische Spiegel der twee laetste navigatiën, bij Joris van "Spilbergen uytgegeven en gedediceert aen de Hoog Mogende Heeren "Staten-Generael ende den Doorluchten Prins van Orangie, is verstaen, "alsoo nog daer veel onwaerheden in is vindende ende 't selve is stry"dende tegen het placcaet van de Hoog Mogende Heeren Staten-Gene"rael, dat men sal trachten 't selve boeck te doen ophouden, door alle "behoorlycke ende mogelycke middelen. Ende syn gecommitteerd de "Heeren Burgemeester Gerrit Jacobsz. Witsen ende Adriaen Pauw Rey“niersz., Raed ende Pensionaris der stad Amsterdam, om 't selve by de "Hoog Mogende Heeren Staten-Generael te vervorderen."

Met welken uitslag deze Commissie te 's Hage is werkzaam geweest, is ons onbekend.

Spilbergen overleed te Bergen op Zoom, den $31^{\text {sten }}$ Januarij 1620. P. A. LEUPE. 


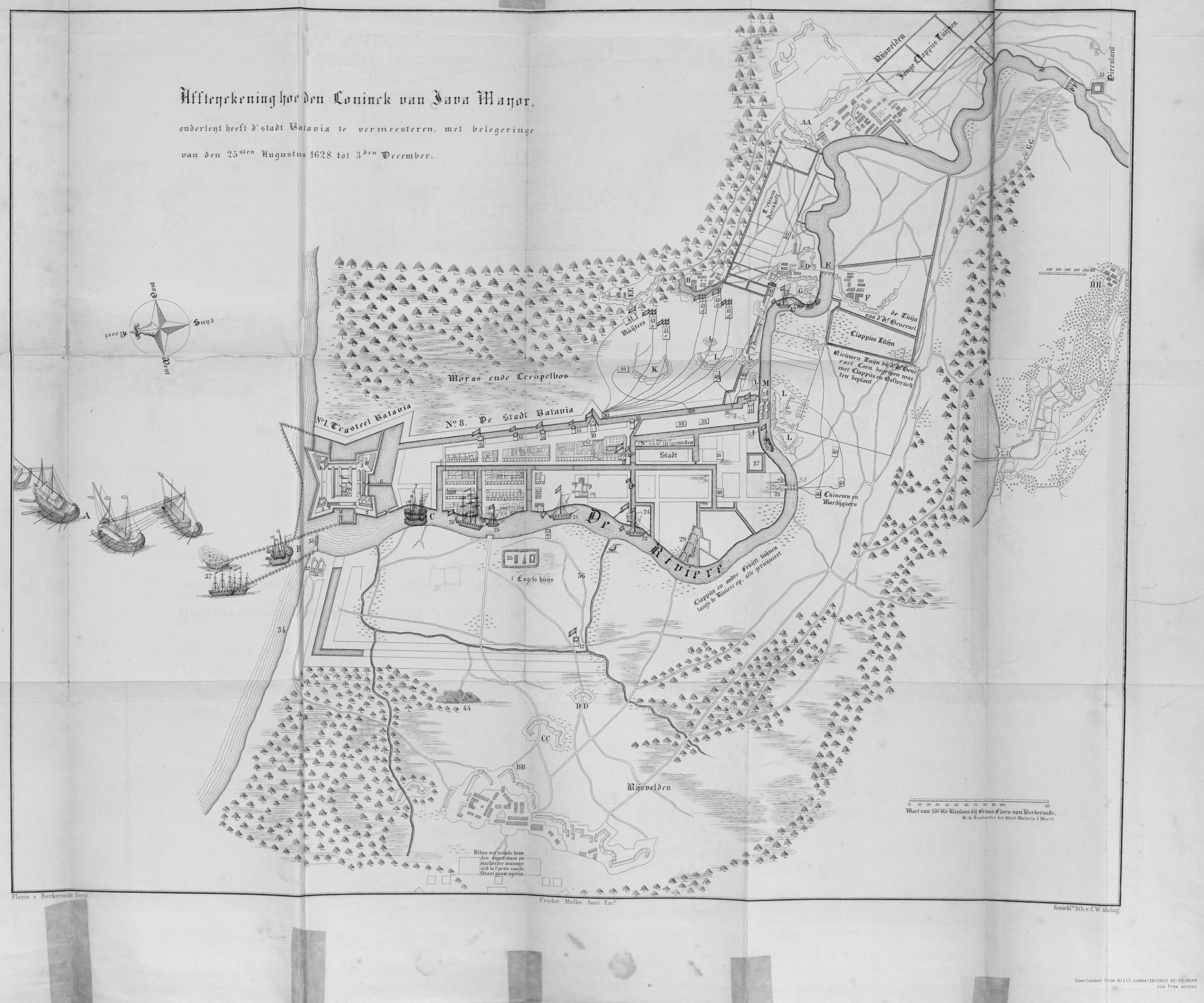

